\title{
ARCHAEOMAGNETIC PROSPECTING AND MODELLING OF IRON AGE SLAGS IN DENMARK.
}

\author{
Niels Abrahamsen ${ }^{1)}$, Uwe Koppelt ${ }^{1,2)}$, Bo Holm Jacobsen", \\ Tatyana Smekalova ${ }^{4)}$ \& Olfert Voss ${ }^{3}$ )
}

1) Dept. of Earth Sciences, Aarhus University, Denmark.

2) Inst. of Geophysics \& Geology, Univ. of Leipzig, Germany.

3) National Museum, Copenhagen, Denmark.

4) Physics Institute, St. Petersburg University, Russia.

The archaeological reconstruction of how iron was produced from Holocene bog-iron ore and charcaal in Denmark during the Iron Age is described. The total number of kilns could to be of the order of 100000 . Search for slags during the last five years by magnetic surveying in general, as well as by magnetic mapping in detail, including simple interactive interpretation by inclined magnetic dipoles (spheres), are illustrated. The mean direction of the magnetic remanence determined by a paleomagnetic study of oriented cores from slag pits, as well as by magnetic inversion of the surface magnetic field from the same slag pits, is further used to obtain a magnetic dating of the slags by comparison with the geomagnetic secular variation. The magnetic mean age of three slag pits thus investigated is found to be between the $2^{\text {ad }}$ and the $5^{\text {th }}$ Century AD.

\section{Prehistoric iron production in Denmark}

Denmark is rather poor in natural resources such as coal and iron-ores for modern industrial production, but bog-iron ore does occur widespread just below the soil as thin, compact layers typically 0.1 an $1 \mathrm{~m}$ thick. Mostly during the Holocene the bog-iron ore was segregated by geochemical processes in the circulating groundwater, and occurs especially in the sandy plains in Jutland west of the limit of the last glaciation. Present day smelting of bog-iron ore is not taking place in Denmark any longer, but metallic iron was earlier produced in Denmark, mainly between the 2nd century BC and 1600 AD (Voss 1993a, b). The production was in periods quite intense, being based upon the locally occurring bog-iron ore and locally produced charcoal. In SW Jutland some 80 places with slag-pit furnaces are known, and the number of slag-pits could be around 100000 . With a production of some $40-50 \mathrm{~kg}$ of metallic iron from each pit, the total production of metallic iron would be 4-5000 tons (Voss 1993a).

The kilns were used only once and destroyed just after the production, but vestiges of the iron production are still often well preserved as slag pits, when not disturbed by the farmers ploughing. The slag pit surface typically lies 0.4-0.5 meter below present-day soil surface. The weight of a slag is typically $200 \pm 100 \mathrm{~kg}$, and due to the high content of iron-oxides it is an easy target to locate by magnetic mapping, which has been used in archaeology since about 1960 (e.g. Aitken 1961, Linington 1964). In Denmark it has been in use since 1964 for mapping of iron-age slag pits, medieval brick-kilns and other constructions (Abrahamsen 1965, 1982, Abrahamsen \& Breiner 1993, Smekalova et al. 1993a, b, 1996, Bevan \& Smekalova 1996, Koppelt et al. 1996, Abrahamsen et al. 1997).

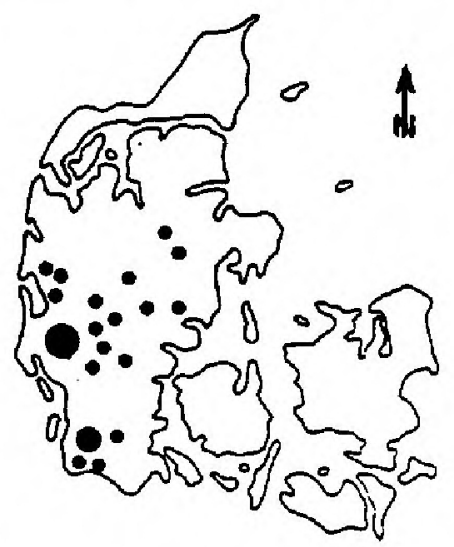

Fig. 1. Index map of Denmark with slag-pit areas shown by dots. The biggest dot indicate the Snorup area in the SW of the Jutland penninsula (from Smekalova et al. 1993 a). 


\section{Iron production at Snorup: Reconstruction and smelting technique}

Shaft furnaces were used in central Europe (e.g. Poland, Ukraine, Denmark) in Iron Age time. Snorup, one of these iron-producing areas, situated in SW Jutland (Fig. 1), comprising of remains of 4000 slag-pit furnaces, dates from the period 100-700 AD (Voss 1993b). The amount of iron produced in prehistoric time may rank this area between the more important prehistoric iron production areas in Europe. Excavations over the years in SW Jutland, and most lately especially in the Snorup area, have revealed details of the original construction of furnaces, as well as of the smelting process itself. The iron production process reconstructed is demonstrated in details in Fig. 2 (Voss 1993b). Full scale experiments with a reconstruction of this type of furnace have been promising and have contributed to the credibility of the reconstruction.

In Poland and Ukraine the socalled "organized" smelting sites found include between 8 and 230 slag-pits. Because of their uniformity these sites are assumed to result from short-term efforts lasting just a few months in the autumn. The clusters in Snorup containing between 28 and 171 slag-pits must also be the result of such short-term productions. The variation in the number of slag-pits in each smelting site in those areas therefore is likely to depend on the amount of charcoal available nearby the site. Furnaces of this type were used only once. The charcoal probably was produced in an oak coppice which could be harvested once every 20 years. This "coppicing" technique of making charcoal was described much later by Duhamel du Monceau (1761). Because of the 20-year cycle of the coppice, charcoal burners were forced continuously to move their craft to another site where the forest was matured for charcoal production. In Denmark coppicing is ancient, dating back to the mesolithic period, in which willow and hazel trees were coppiced to provide materials for fishing traps and weirs.

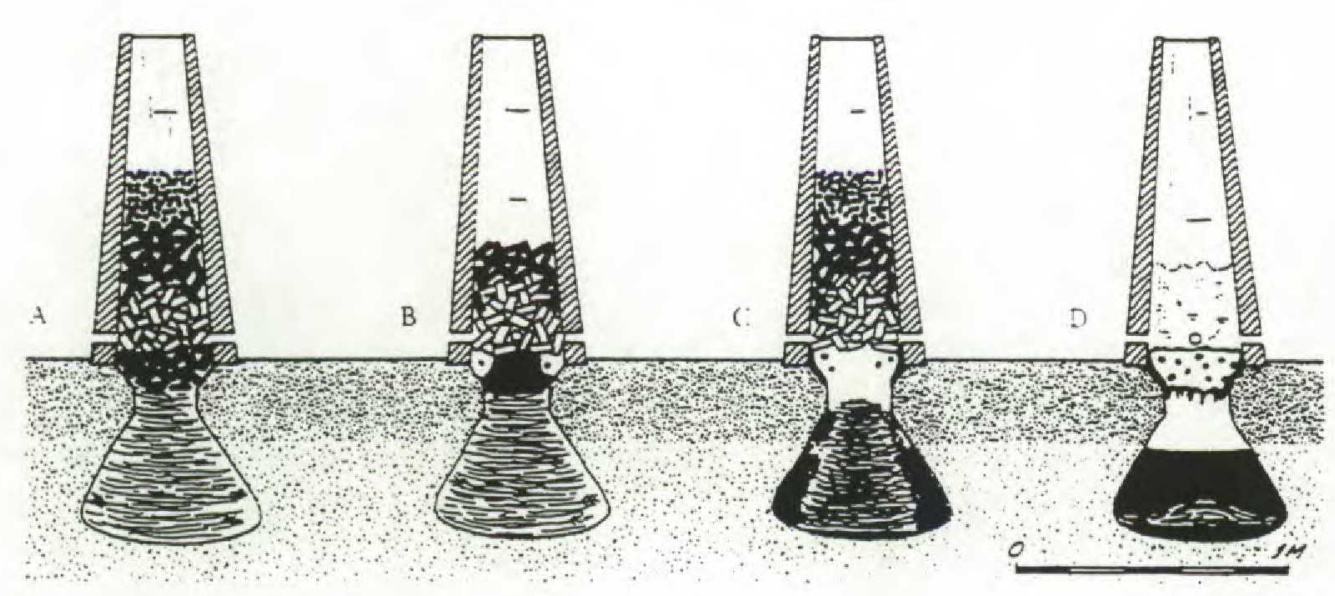

Fig. 2. Reconstruction of slag production from bog-iron ore and charcoal. A: The slag-pit is dug and stuffed with straw, preventing the charcoal and ore in the $1.2 \mathrm{~m}$ high kiln from falling down. Fresh air is supplied via the holes at the base. The glowing charcoal developes $\mathrm{CO}$-gas, which reduces the ironoxides to the metallic spongy iron, filling holes in the slag. B: When the iron-sponge sinks down to the zone with a temperature of $12-1300^{\circ} \mathrm{C}$ just above the air-holes, the slag smelts completely and runs down, being stopped at first by the straw. C: After some time the weight of the accumulating liquid slag compresses the straw and runs down in the hole, solidifying immediately to a thin plate. D: Now the kiln has been heated so much, that the liquid slag produced afterwards do not crystallize in the upper part of the kiln in contrast to the metallic iron, which (having a somewhat higher smelting temperature) is typically caught at the sides just under the air-holes. Continued heating in 48 hours, adding sequentially shifting layers of charcoal and bog-iron ore ( $280 \mathrm{~kg}$ of each) in the kiln, produced c. $60 \mathrm{~kg}$ of metallic spongy iron-luppe, according to analysis of slag and iron ore from the same furnace (Voss 1993b). 


\section{Magnetic prospecting and dipolemodelling of the slags}

Because of the superficial position, the high magnetic susceptibility, and the strong remanent magnetization of the slags (as compared to the magnetically fairly neutral surrounding sediments), a local magnetic survey is a very effective way of finding the exact locations, the areal extent and even the numbers of the still remaining slag pits.

In Fig. 3 the total field magnetic gradient anomaly of a surveyed slag area $\mathrm{C}$ in Snorup, is shown. Individual slag pits show up as rather circular anomalies, in this case with amplitudes typically between 30 and $100 \mathrm{nT}$. When the slags are more than one slag dimension from each other, the number of individual slags may be counted just from the number of almost circular magnetic anomalies. Elongated and more irregular shaped anomalies indicate slag rows or clusters. Within the clusters the number of individual slag pits are more difficult to evaluate. Measurements were made by a Geometrics proton gradiometer at NS profiles in a $1 / 4 \mathrm{~m}^{*} 1 / 4 \mathrm{~m}$ grid. Simple magnetic modelling by adjusting a number of inclined dipoles programmed for MATLAB was used to model the position, depth and dipolemoment of the slags.

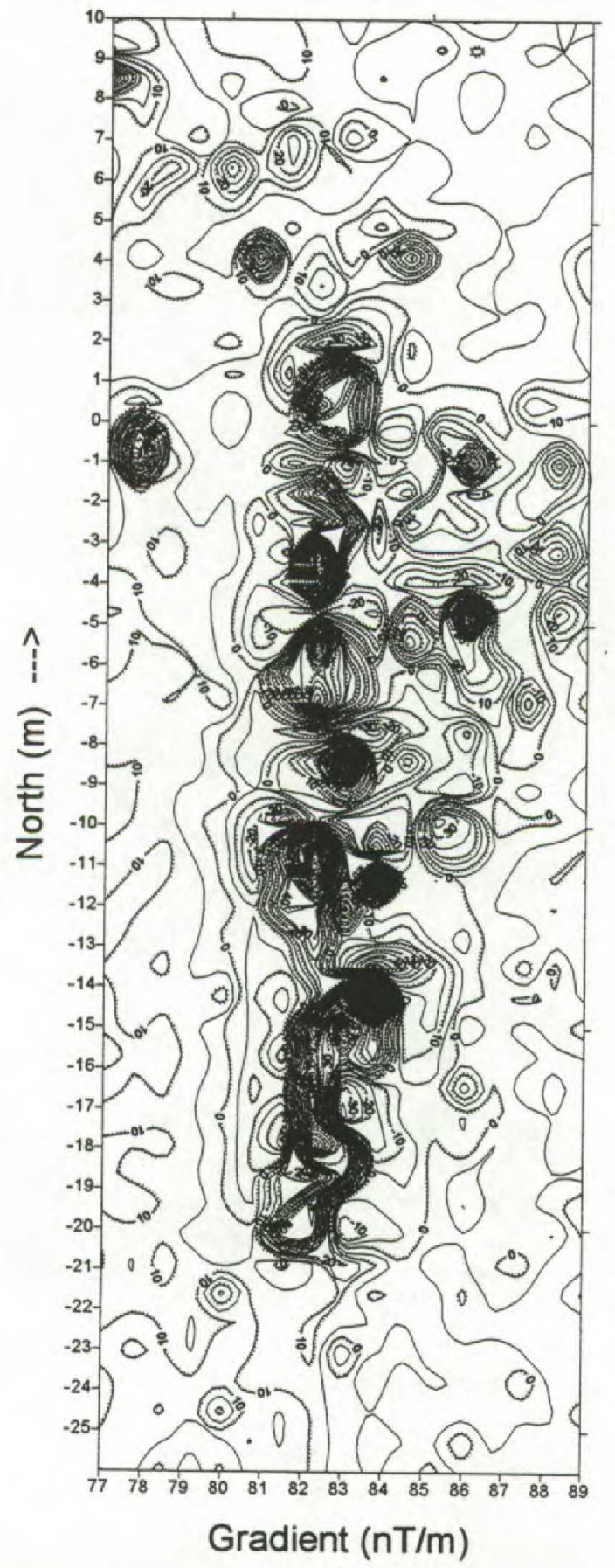

Fig. 3. Total field magnetic gradient over slag area $\mathrm{C}$ in Snorup.

Fig. 4. Magnetic secular variation in Snorup (Denmark) for the period 0 to $2000 \mathrm{AD}$, based upon a central dipole transformation of the British mastercurve from UK to Denmark (Abrahamsen 1996). Small numbers indicate century AD. The directional results for the slag pits E16, E24 and E25 obtained by magnetic cleaning of oriented cores (small solid dots) and by inversion (open dots) are also shown. Solid dot and corresponding $95 \%$ significance circle indicate the overall mean direction.

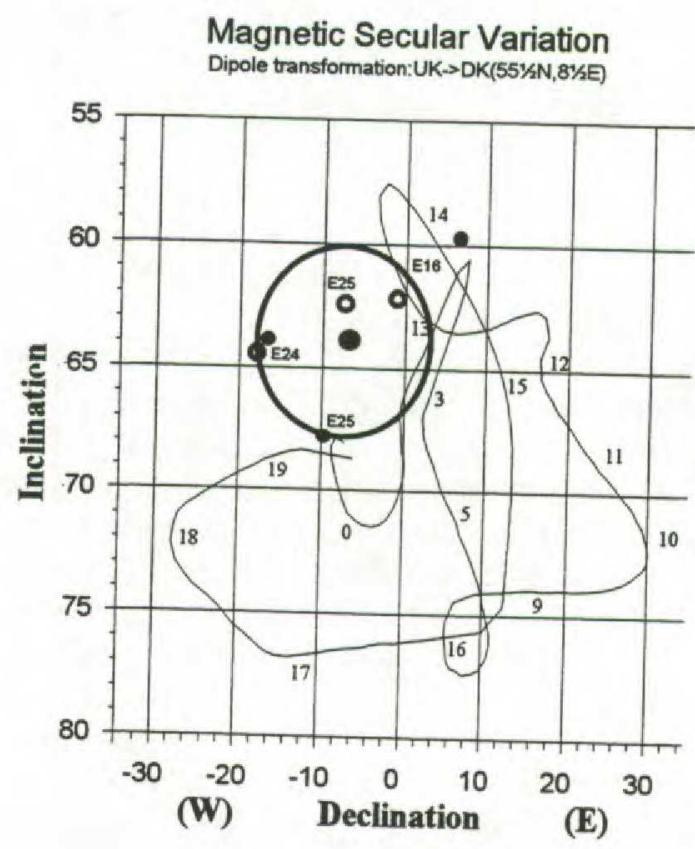




\section{Paleomagnetic results and magnetic dating}

Archaeologically the slags are difficult to date in detail, the wood and straw usually being totally burned, and tools are rarely found associated with the slags. To investigate in more details the remanent magnetization properties, as a possible tool for magnetic dating of the slags by the geomagnetic secular variation, three undisturbed slag pits (E16, E24 and E25) from Field $\mathrm{E}$ have been paleomagnetically sampled in situ, using a portable, water-cooled drill, and later measured on a spinner magnetometer, using standard stepwise AF demagnetization. After a detailed magnetic survey over the same slag pits, magnetic modelling by inversion of the total magnetic field anomaly produced a modelling mean direction (Koppelt 1996). There is a fair correspondence between the two sets of mean directions for each slag (Fig 4).

The magnetic secular variation curve for Denmark for the period 0 to $2000 \mathrm{AD}$ is also shown. This curve is based upon the British archaeomagnetic mastercurve (Clark et al. 1988), recalculated from UK to Denmark by a central dipole transformation (Abrahamsen 1993), a distance of $800 \mathrm{~km}$. The $\alpha_{95}$-circle shown is the $95 \%$ significance circle of the combined mean direction. The paleomagnetically determined directions appear rather scattered (solid dots), and a dating based upon these alone is not well constrained $\left(\alpha_{95}=7^{\circ}\right)$, the direction suggesting a paleomagnetic age of before the $6^{\text {th }}$ Century $\mathrm{AD}$. The inverted mean directions are less scattered (open dots) and the trend is in general agreement with the paleomagnetic mean directions. Although scattered, the two magnetic techniques thus support each other.

The grand mean of all 6 mean directions gives a value of $(D, I)=\left(352.8^{0}, 63.6^{\circ}\right), \alpha_{95}=$ $3.76^{\circ}, \mathrm{k}=260$. Considering the uncertainties of the magnetic master-curve, which may well be at least $\pm 2^{0}$ in inclination and $\pm 5^{0}$ in declinaion, the magnetic mean direction suggests an age of the three slag pits in Field $\mathrm{E}$ between the $1^{\text {st }}$ and $5^{\text {th }}$ Century $\mathrm{AD}$.

\section{References}

Abrahamsen, N., 1965: Archeomagnetism og Iron Age slags. Kuml 1965, 115-132.

Abrahamsen, N, 1967: Some archaeomagnetic investigations in Denmark. Prospezioni Archeologiche 2, 95-97. Abrahamsen, N., 1982: Magnetic experiments on reconstructed kilns. Proceedings Second Nordic Conference on the Applications of Scientific Methods in Archaeology. PACT, 427-428.

Abrahamsen, N., 1996: An archaeomagnetic mastercurve for Denmark 0-2000 AD and the possible dating accuracy, 261-271. Proceedings Sixth Nordic Conf. on the Application of Scientific Methods in Archaeology, Esbjerg Museum, 1993.

Aitken, M., 1961. Physics and Archaeology. Interscience Publ. New York. 180 pp.

Clark, A.J., Tarling, D.H. \& Noël, M., 1988: Developments in Archaeomagnetic datings in Britain. $J$. Archaeological Science 15, 645-667.

Duhamel du Monceau, H.L., 1761: Art du Charbonnier ou Manière de faire le Charbon de Bois. Paris, 1761.

Koppelt, U., 1996: Geomagnetische Erkundung archäologischer Objekte. Forschungsbericht, Institut für Geophysik und Geologie, Universität Leipzig; $42 \mathrm{p}$.

Koppelt, U., Abrahamsen,. N., Jacobsen, B.H., Smekalova, T., Voss, O. \& Bevan, B., 1996: Resolution of "vertical gradient (?)" measurements in archaeomagnetism. Annales Geophysicae 14, Supplement 1, 162.

Linington, RE., 1964: The use of simplified anomalies in magnetic surveying. Archaeometry 7, 3-13.

Smekalova, T., Voss, O. \& Abrahamsen, N., 1993a: Magnetic investigation of iron-smelting centres at Snorup, Denmark. Archaeologia Polona, 31, 83-103.

Smekalova, T., Abrahamsen, N. \& Voss, O., 1993b: Magnetisk detektering af jernudvindingspladser med slaggegnuber. Arkaologiske udgravninger $i$ Danmark 1992, 7-20. Nationalmuseet, Kobenhavn.

Smekalova, T., Abrahamsen, N. \& Voss, O., 1996: Magnetic investigation of a Roman/Early Germanic Iron Age iron-smelting center at Snonup, Denmark. Proceedings Sixth Nordic Conf. on the Application of Scientific Methods in Archaeology 1993, 227-245; Arkzologiske Rapporter nr. 1, 1996; Esbjerg Museum. Voss, O., 1962: Jernudvinding i Danmark i forhistorisk tid. Kuml 1962, 7-32.

Voss, O., 1991: Jernproduktionen i Danmark i perioden 0-550 e. Kr. Jysk Arkoeol Selskabs Skrifter 27, 71-184. Voss, O., 1993a: Iron smelting. In Hvass, S. \& Storgaard, B. (eds.) Da klinger $i$ Muld.. 25 ärs arkcoologi $i$ Danmark, 206-209. Aarhus Universitetsforlag, Aarhus.

Voss, O., 1993b: Snorup. Et jernudvindingsområde i Sydvestjylland. Nationalmus. Arbejdsmark 1993, 97-111. 